e.g., of a connexion between genius and epilepsy, never very widely favoured by physicians, may now be regarded as definitely disproved. Nor are the weak and diseased tendencies, of which genius has been actually convicted, of a kjnd which any sensible person would regard as prohibitive of marriage. In a quite different category, however, from these is the case in which an individual who possesses genius may have constitutional proclivities which make it likely that his children, if he had any, would be insane or tuberculous or epileptic. Und $r$ such circumstances the possibility that genius might be transmitted would be no excuse for the physician who should recommend marriage nor, a fortiori, could the fact that genius has had a tendency to occur in a family which has produced many lunatics be considert $d$ to palliate the marriage of a member of such a family who was himself neither a genius nor quite sound mentally. It is significant in this connexion that none of the distinguished men who have advocated the degeneration theory have even binted that it is wrong to discourage "philoprogenitiveness" in degenerates. It has remained for your correspondent to make the suggestion.

Not only are some of us living in an antedilnvian world, in which contemporary tendencies play no part, but we often seem blind to facts of every-day experience. The facts which I have more especially in view are to ke met with at any school-attendance committee meeting in our large cities. There, for their part not a little astonished at the special attention they receive, families present themselves, organised on a basis like this. A father who is a drunkard or epileptic incapable of steady employment, occasionally picking up a few shillings in the lowest lines of casual labour; a wife supporting the family by her earnings; six or seven weakminded children, who in the necessary absence or frequent confinements of the mother stay at home to do the work of the house. Is this, one is tempted to ask, a fair illustration of the working out of that latest discovery in the higher ethics, the precept, i e., that we ought to care for the individual and leave the race and the future to look after themselves?

As regards the outlook, were we to judge by the views of some of your correspondents there would indeed be grounds for serious misgiving. For my part I have much coufidence in the growth of a saner opinion, of which th ere are everywhere so many indications, and cannot doubt that, under the pressure of these new ideas, we shall have in the near future a large and wholly bentficent extension of sterilisation as a remedy fur the terrible evils from which we at present suffer. I am, Sir, yours faithfully,

Stoke Newington, Sept. 23rd, 1911.

I. B. MUIRHEAD.

\section{THE NOMENCLATURE OF SPINAL DEFORMITIES.}

To the Editor of THE LANCET.

SIR,- In your issue of Sept. 2nd appears an article on Spinal Carvatures and their Treatment, \&c. Will you allow me space to call attention to the confusing terminology adopted by the author of that article, and to urge upon bim and others interested in these deformities the use of a more accurate nomenclature? He writes of several conditions which I will enumerate in turn. 1. In the title of his paper he uses the phrase "spinal curvatures" to include all deformities of the spine-e.g., Pott's angular kyphosis, scoliosis, kyphosis, lordosis, spondylitis, \&c. 2. On p. 667, line 23, he uses "spinal curvature" to mean scoliosis. 3. On p. 668, line 9, he writes of "lateral deviation," and in the next line of a "more or less fixed scoliosis" (4) 5. On p. 668, line 47, he writes of "scoliusis." 6. On p. 669 , line 23, of "simple lateral deviation." 7. On p. 669, line 24, of " "a curve in the second degree of severity" - that is, a 'true scoliosis,' but not yet fixed" (8). 9: On p. 669 , line 40, he uses "fixed curvature" to mean the angular kyphosis of Pott's disease. And fina'ly, (10) on p. 671, line 10, he writes of "lateral curvatures"

Now, Sir, these terms are so used throughout his article that it is very difficult to follow the author's line of thought. Yet by nsing the simple method I now suggest all confusion would disappear. 1. Omit the phrase "spinal curvatures" of his title altogether and substitute for it "spinal de. formities." 2. Write of the deformity produced by Pott's disease as "spinal caries deformity" or "Pott's angular kyphosis." 3. Write of the lateral curvature of the spine in which there is as yet no bony deformity as "postura] scoliosis," or "postural lateral curvature." 4. Write of the lateral curvature of the spine in which bony deformity is present as "osseous scoliosis," or "osseous lateral curvature."

Let future authors drop all such terms as "lateral deviation," "more or less fixed scoliosis," "true scoliosis," "fixed curvature," and "a curve in the second degree of severity"; then we shall know exactly what the authors mean. I am, Sir, yours faithfully, Harley-street, W., Sept. 25th, 1911. Paul B. Roth,

\section{CHRONIC OBSTRUCTION OF THE BOWEL} IN A HYDROCEPHALIC IMBECILE.

\author{
To the Ealitor of THE LANCET.
}

Sir,-In The LanceT of Sept. 16th, p. 820, a very interesting case is described under the above heading by $\mathrm{Dr}$ A. L. E. F. Coleman and Dr. H. D. Everington. I should like to point out that this case is a typical example of so-called "congenital dilatation of the colon," better called "congenital hypertrophy and dilatation of the colon" (known in Germany as Hirschsprung's disease). The dilatation and thickening of the bowel were not due, as the authors supposed, to chronic constipation, but were the cause of it. I collected a number of these cases for the Jacksonian Essay of 1908 and they will be found in my book on "Diseases of the Colon." I am, Sir, yours faithfully,

P. LOCKhan'T MUMMERY,

Cavendish-place, W., Sept. 20th, 1911.

\section{BRITISH HEALTH RESORTS FOR FOREIGN INVALIDS.}

To the Editor of TH $\mathrm{E}$ LANCET.

SIR,-For the furtherance of a movement which may prove advantageous to two great and friendly countries may I ask you to be so very kind as to inform your readers that, taking cognisance of Dr. Neville Wood's paper "British Health Resorts for Fortign Invalids," read before the Royal Society of Medicine and published in THE LANCE'T of Jan. 7th, p. 12 the French Government has commissioned me to visit the principal health resorts of Great Britain and to issne a report on their suitability for various categories of French invalids, and at the same time to inquire into the practice and teaching of hydrology in the medical schools attached to universities.

I hope at an early date to arrive in London, where $m$ postal address will be the Rojal Society of Medicine, 15, Cavendish.square. Thanking you in anticipation, I am, Sir, yours faithfully,

Gustaye Monod, M.D. Paris, L.R C.P. Lond. M. R.C.S. Eng.,

Sept. 23rd, 1911. Médecin Consultant à Vichy.

\section{ANASTHETICS IN INTESTINAL OBSTRUCTION.}

To the Editor of THE LANCET.

SIR,-- Following the publication of my clinical notes (of a. death under an anæsthetic) in your issue of May 20th last. there were several interesting and valuable comments and suggestions in your correspondence columns. All the methods advised for the prevention of such "drowning fatalities" are quite adequate, but some of them have the defect of being complicated to a degree which must lessen the patient's chance of recovery. I refer more particularly to the operation of prtliminary tracheotomy with packing the larynx.

In a recent case of complete obstruction, a very old woman, who had fæcal vomiting, a preliminary injection of morphine $\frac{1}{4}$ gr. and atropine $\frac{1}{60}$ gr. was given. This. produced deep somnolence. Atter administering a very few drops cf chloroform $c n$ a flannel mask the operation was begun, and at the same time the mouth was opened and sponged out; some dark matter being. present; the osophageal tube was passed and the stomach 